\title{
Tariff discrimination on Brazil's soluble coffee: an economic analysis
}

\author{
MARISLEI NISHIJIMA* \\ MARIA SYLVIA MACCHIONE SAES**
}

This article evaluates the impacts of the imposition of tariffs on the Brazilian soluble coffee mainly by European countries as of the 1990s. More particularly, it verifies whether the imposition of discriminatory trade tariffs by the European Union and of non-discriminatory ones by some Eastern European countries reflects on the international demand for this commodity. For this purpose, dynamic models of global demand for Brazilian soluble coffee were estimated for the 1995-2003 period using data from the International Coffee Organization. Findings suggest that existing tariffs significantly account for the reduction of Brazilian share of soluble in the world market.

Keywords: soluble (instant) coffee; tariffs; welfare; demand; Brazil.

JEL Classification: C01;C51; L16.

Though Brazil leads the world in soluble coffee production and exports ${ }^{1}$, its share in the global market has decreased since 1993: from 31\% in 1992 to $15 \%^{2}$ of that market as of 1998. What accounted for the country's relative loss of market share was the limited growth of its domestic market in comparison to that of the world market. The increase in soluble coffee world exports found its supply mainly in traditionally consuming and non-producing countries. Singapore expanded

\footnotetext{
* Escola de Artes, Ciências e Humanidades da Universidade de São Paulo - EACH-USP. E-mail: marislein@gmail.com.

** Faculdade de Economia, Administração e Contabilidade da Universidade de São Paulo - FEA-USP. E-mail: sylviasaes@gmail.com . The authors thank two anonymous revisers for the suggestions and to Marco Conejero. Submitted: February 2007; Approved: November 2008.

${ }^{1}$ Saes (1997).

${ }^{2}$ Market size measured in $60 \mathrm{~kg}$ bags of green coffee (conversion: net weight $* 1000 * 2,6 / 60$ ), as per the International Coffee Organization (ICO).
} 
its world market share from $5 \%$ to $10 \%$; Malaysia started exporting to $7 \%$ of the global market; Spain and the Following the increase in soluble coffee exports worldwide, there was a decrease in prices paid to Brazilian exporters in the international market as result of increased competition. Brazilian soluble coffee exports have been a target for both discriminatory tariffs mainly by European countries, and for non-discriminatory ones by some Eastern European countries. Thus this study aims to verify whether those tariffs can account for the relative loss this commodity suffered in the world market ${ }^{3}$ and to discuss the fall in the welfare caused by discriminatory ones.

For this purpose, the article is divided into five parts, including this Introduction: the first part presents a brief overview of the participation of the Brazilian instant coffee in the international market as of the 1990s. The second part discusses the tariff restrictions on trade faced by the Brazilian soluble coffee. The third part discusses the economic effects on welfare of using tariffs relative to free trade for a producing country with no comparative advantage for a specific commodity. The fourth part presents the estimated models to evaluate the effects of the tariffs on the Brazilian soluble coffee demand. Finally, the main conclusions of the study are summarized in last part.

\section{THE BRAZILIAN SOLUBLE COFFEE INDUSTRY}

We supposed that Brazil — despite its relative loss in the world market — has comparative advantage in producing soluble coffee insofar as it is the world's largest producer and exporter of the arabica green coffee and one of the largest exporters of the robusta green coffee, the main input of soluble coffee.

The Brazilian soluble coffee industry ${ }^{4}$ was implemented in the 1960s through government incentives aimed at reducing the high costs of the low quality green coffee stocks to meet external demand. In the early 1990s, however, Brazil started to reduce its relative participation in the world market of soluble coffee, as seen in Table 1. Colombia and Ecuador, both traditional producers of soluble coffee, also lost relative market shares. Non-traditional producers started to take on leading positions, mainly Asian countries such as Singapore and Malaysia, which increased their relative share by $5 \%$ and $6 \%$, respectively, through $1995-2003$. Developed countries also increased their share in the same period: Spain by $3 \%$; the Netherlands by $3 \%$; the US by $2 \%$; and Germany by $2 \%$. Nevertheless, despite those changes in relative market positions in the world market of soluble coffee, few countries

\footnotetext{
${ }^{3}$ For the Brazilian soluble coffee industry, the world market is what matters. Though domestic consumption has grown and gained importance in the last few years, a full $87 \%$ of the soluble produced in the country is exported (ABICS, 2005).

${ }^{4}$ For a detailed history of the origins of soluble coffee industry see Talbot (1997).
} 
reduced their export quantity; on the contrary, world exports increased by $94 \%$ between 1995 and 2002.

Countries that did not use to produce green coffee were able to garner a larger share of the soluble coffee market either by benefiting from the great availability of the raw material at low prices in the international market or by packing soluble coffee purchased in bulk quantities. Overall world exports of green coffee over 1995-2004 presented a cumulative 20\% increase, according to International Coffee Organization (ICO). Brazil and Vietnam were the main countries responsible for this growth: the former captured $29 \%$ of the world market in 2004 against the $21 \%$ held in 1995 ; and the latter $16 \%$ of this market in 2004 , up from a mere $5 \%$ in 1995 .

Green coffee beans of robusta coffee - the relevant type in the world manufacture of soluble coffee - have lower prices than the arabica beans in the international market, besides giving a better yield ${ }^{5}$. Vietnam largely accounted for the increased supply of the main input of soluble coffee in the international market, producing the robusta coffee nearly exclusively. This country increased its production by 10 millions bags between 1995 and 2004, being the largest world exporter of this variety, accounting for $43 \%$ of the world market in 2001. The large increase in Vietnam's production capacity was driven by a World Bank incentive program for poor countries (the Poverty and Growth Program of the World Bank Institute). Brazil's product shared the fourth place with the Ugandan robusta coffee in the same year in the ranking of world exporters.

The huge increase in the quantity of negotiated green coffee in the world market resulted in a steady decrease in its international price. Graph 1 shows the price behavior in dollars of the robusta coffee per ton. The production cost of soluble coffee has dramatically decreased in the last few years, which in part explains the recent drop in soluble coffee prices in the international market.

As the international prices of green coffee decreased, so did the international price of the soluble coffee exported by Brazil, but at a higher rate. This suggests a reduction in the profit margins made by Brazilian producers of soluble coffee and increased competition in the world market of soluble coffee.

\footnotetext{
${ }^{5}$ It allows for an estimated rate of extraction of soluble solids of $40 \%$ against $35 \%$ to $37 \%$ of the arabica species.
} 


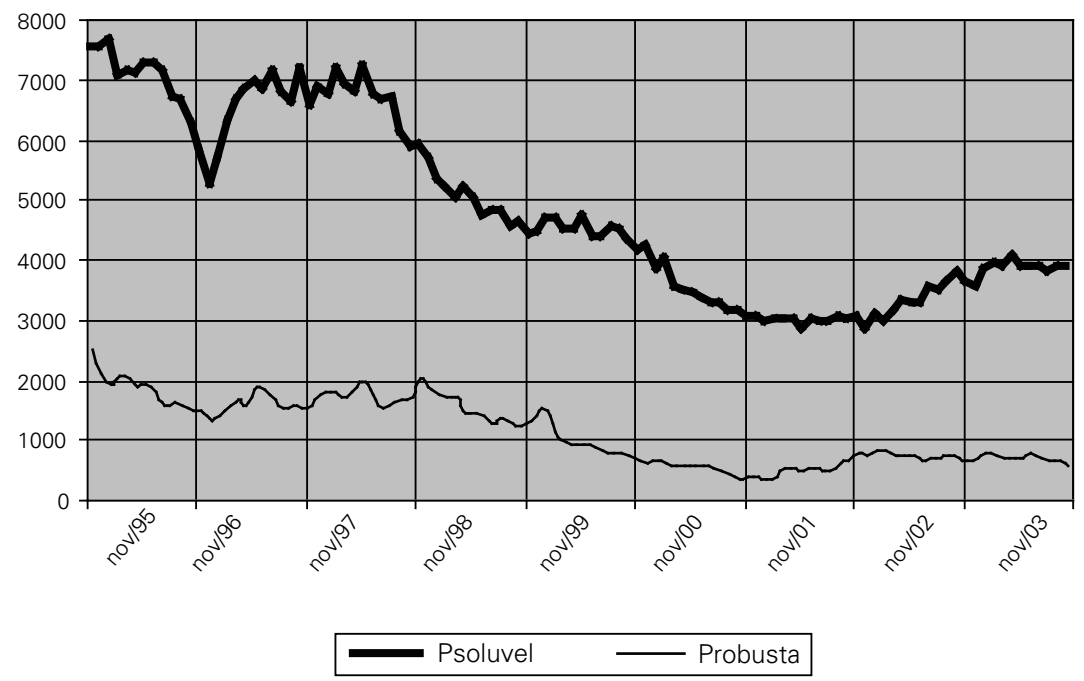

Source: International Coffee Organization (2005).

\section{TARIFF PROBLEMS FACED BY BRAZILIAN SOLUBLE COFFEE}

The European Union (EU) tariff discrimination system toward Brazilian soluble coffee was started in 1991, within the framework of the Generalized System of Preferences (GSP) scheme effective in 1990. The GSP granted customs exemptions for some Latin American countries - including Colombia - as part of the operational cooperation against drug trafficking, characterized as Drug Regime (DR). But the GSP maintained a rate of taxation of $9 \%$ on imports of Brazilian soluble coffee and of $8.5 \%$ on Mexico's and India's. In 1996, the EU reassessed the GSP and set forth a new mechanism for a decrease in or exemption from duties according to the degree of economic development of the countries. Being considered as a developed country, as of January 1997 Brazil had a 10.1\% import tariff imposed by the EU, as seen in Table 2. Andean Pact countries, though, continued to enjoy the exemption.

After the approval of the 1990 discriminatory policy, the Brazilian Association of the Soluble Coffee Industry (ABICS) had started several actions to reverse the EU's position ${ }^{6}$. But despite the fact that $\mathrm{NERA}^{7}$ analysis pointing out several eco-

\footnotetext{
${ }^{6}$ In March 1997, lawyers hired by the association concluded that there were legal bases for the claim (Malta, 2004).

${ }^{7}$ National Economic Research Associates, Inc; White Plains, NY.
} 
nomic arguments able to sustain a claim together with the World Trade Organization (WTO), Brazil did not manage to reverse its position. In May 2001, after several negotiations - including those occurring after the case had been taken to the WTO's Dispute Settlement Body (DSB) - the Europeans established a quota system for Brazil, under the Most Favored Nation (MFN) clause ${ }^{8}$. Still, according to this system, quantities negotiated above the quota would continue to face the tariff of 9\% (OJEC, 2001).

Brazil had unsuccessfully pointed out in the above-mentioned negotiations the need to adjust the volume of quotas in case the EU decided to admit new membercountries. After May 2004, ten new countries, significant importers of Brazilian soluble coffee, became members of the EU thereby creating an impasse. At the end the EU (including its new members) took out the quota system and set a tariff of $9 \%$ for Brazilian coffee. With respect to the Mercosul-EU negotiations then under way, the Brazilian industry proposed either to include soluble coffee in Category $\mathrm{A}^{9}$, thus eliminating the quota system and making all Brazilian exports of soluble coffee duty free; or, alternatively, to include this product in Category $\mathrm{B}^{10}$, thus increasing Brazilian soluble coffee import quota.

Table 3 summarizes the history of soluble coffee imports made by the EU after 1990 per country of origin. Whereas the overall imports of soluble coffee by the EU almost doubled from 1990 to 2003, total imports of soluble coffee from Brazil decreased along the 1990 s, from $20.5 \%$ in 1993 to $6.2 \%$ in 1999 , growing again only after 2002, when the quota regime was enforced.

The Brazilian industry of soluble coffee was also hampered in the 1990s by the cut in Soviet imports in 1991. Both the return of Russia to the market in 1993 and the recovery of coffee prices in the world market favored Brazil's soluble coffee exports as compared with previous years (Zylbersztajn et al., 1993). Nevertheless, Brazilian soluble coffee exports to Russia - which in the early 1990s had been Brazil's main buyer — decreased dramatically as of 1993. Russia, as well as Ukraine - another great importer of Brazilian soluble coffee - adopted policies of high import tariffs to foster their domestic production. According to the ICO, the current tariff for importing soluble coffee into the Russian Federation is $15 \%$ and into Ukraine is $30 \%$. Other countries in the European East also have high import tariffs for soluble coffee, among them Hungary (35\%), Bulgaria (25\%) and Romania

\footnotetext{
${ }^{8}$ The Most Favored Nation clause establishes that any advantage, favor, privilege or immunity granted by any contracting party to any product originating in or destined for any other country shall be accorded immediately and unconditionally to the like product originating in or destined for the territories of all other contracting parties.

${ }^{9}$ Category A includes products whose tariff would be immediately cut in the Mercosur-EU agreement.

${ }^{10}$ Inclusion in this category would increase the Brazilian soluble coffee imports quota, through the introduction of a percentage rate taking into account the Brazilian position in the expanded European market.
} 
$(19 \%)$. This policy of fostering domestic production implies that Brazil tends to lose those markets definitely (Saes \& Nakazone, 2003).

In addition to the EU and Eastern European countries, other countries impose discriminatory tariffs on Brazilian soluble coffee. For instance, China levied a tariff of $44 \%$, reduced to $30 \%$ after it joined the WCO, and Mexico levies a $141 \%$ tariff (Malta, 2004).

Although the US does not levy a tax on Brazilian soluble coffee, the decade witnessed campaigns to reduce the consumption of coffee in general, which caused the consumption of this good to drop from approximately 0.46 cups daily in the 1980s to 0.18 cups daily between 1990 and 2004 (USDA ${ }^{11}, 2005$ ). Nevertheless, in 2003 the US was the biggest buyer of Brazilian soluble coffee, as seen in Table 3 , having almost single-handedly bought soluble coffee in bulk. Even though the US has production plants for soluble coffee installed, Brazil sells this good in bulk at prices lower than those at which the North-Americans can produce, so it is more advantageous for the latter to buy from Brazil, and package and sell the product in its market (Malta, 2004). This behavior signals that Brazil has indeed been having comparative advantage ${ }^{12}$ in producing this good, although it also suggests that the US demand is very price elastic, insofar as this country is capable of producing soluble coffee domestically should the price of this Brazilian commodity grow excessively.

It is worth noting that despite the discriminatory import tariffs, Germany's volume of imports from Brazil increase, as seen in Table 4. One such reason may be this country imports soluble coffee in bulk from Brazil, like the US, and re-exports the produce packaged and labeled, mainly to the $\mathrm{EU}^{13}$.

\section{THE INEFFICIENCY OF DISCRIMINATORY AND NON-DISCRIMINATORY TARIFFS}

According to Rieber (1981), different tariff levies on a commodity can induce a country which has a single producer ${ }^{14}$ (monopoly) since to protect its incipient industry until to become internationally competitive, even without having a comparative advantage in exporting this commodity. However, these possibilities may

\footnotetext{
${ }^{11}$ United States Department of Agriculture, site accessed in November, <http://www.usda.gov/wps/portal/usdahome $>$.

12 This has been happening even though there is no drawback mechanism for green coffee in Brazil, as in Colombia.

${ }^{13}$ Germany also acts likewise with Brazilian green coffee, buying a homogeneous produce and fostering its differentiation through the marketing of its own brands.

${ }^{14}$ Note that if the domestic market of a good is perfectly competitive, the tariff cannot reverse the trade flows.
} 
imply loss of welfare in relation to a situation of free trade, as traditional international economic literature points out. This model is adequate to analyses, for instance, the Russia case, since it imposes tariffs on the soluble coffee from all origins to foster its domestic industry growth and because the costs for implementing soluble coffee facilities are very high (Saes, 1997). We assumed the world soluble coffee market to be competitive, even though Brazil is a large supplier, because of the many newcomers in the last decade and the dramatic fall in the commodity's international price, as seen above.

Panel $A$ in Figure 1 depicts the economic analysis of Rieber (1981). If there are free trade flows, the equilibrium occurs in the $b$ point. If the country tariffs by $t_{1}$ rate, the domestic price will be $\left(1+t_{1}\right) P_{w}$-, being $P_{w}$ the international competitive price of the commodity - the domestic firm sells $0 q_{3}$ units and the country imports $\mathrm{q}_{3} \mathrm{q}_{5}$ and loses $\mathrm{M}$ area of welfare compared with free trade. If the tariff rate is $t_{2}$, this commodity is no longer traded internationally, i.e., all domestic demand is satisfied by domestic firms. The equilibrium is $0 \mathrm{q}_{4}$ units at the price $\left(1+\mathrm{t}_{2}\right) \mathrm{P}_{\mathrm{w}}$ and the loss of welfare is the sum of the G, L and M areas. As for tariffs higher than $t_{2}$, the domestic producer behaves as a monopolist. Also, for tariff rates between $t_{2}$ and $t_{3}$, the domestic producer charges the international price plus tariffs. If $t_{3}$ is the charged tariff rate, the domestic producer comes back to its initial position selling the same quantity as in free trade; however, the deadweight loss corresponds to the sum of C, F, G, E, I, J, K, L, M areas. Additionally, the marginal cost of the domestic producer at this rate is equal to $\mathrm{P}_{\mathrm{w}}$, but its marginal revenue is lower than that. Thus, for a tariff rate higher than $\mathrm{t} 3$, producers start discriminating prices, selling part of their production in the international market at $\mathrm{P}_{\mathrm{w}}$ and part in domestic market at a higher price. Finally, at a tariff equal to or above $t 4$, it is more rational for domestic producers to export their production to the international market at $\mathrm{P}_{\mathrm{w}}$ than to sell it domestically, even though there is not comparative advantage in producing the commodity. Thus, the higher is the tariff rate the higher is the deadweight loss in relation to free trade. 
Figure 1: Non-discriminatory and discriminatory tariff welfare effects
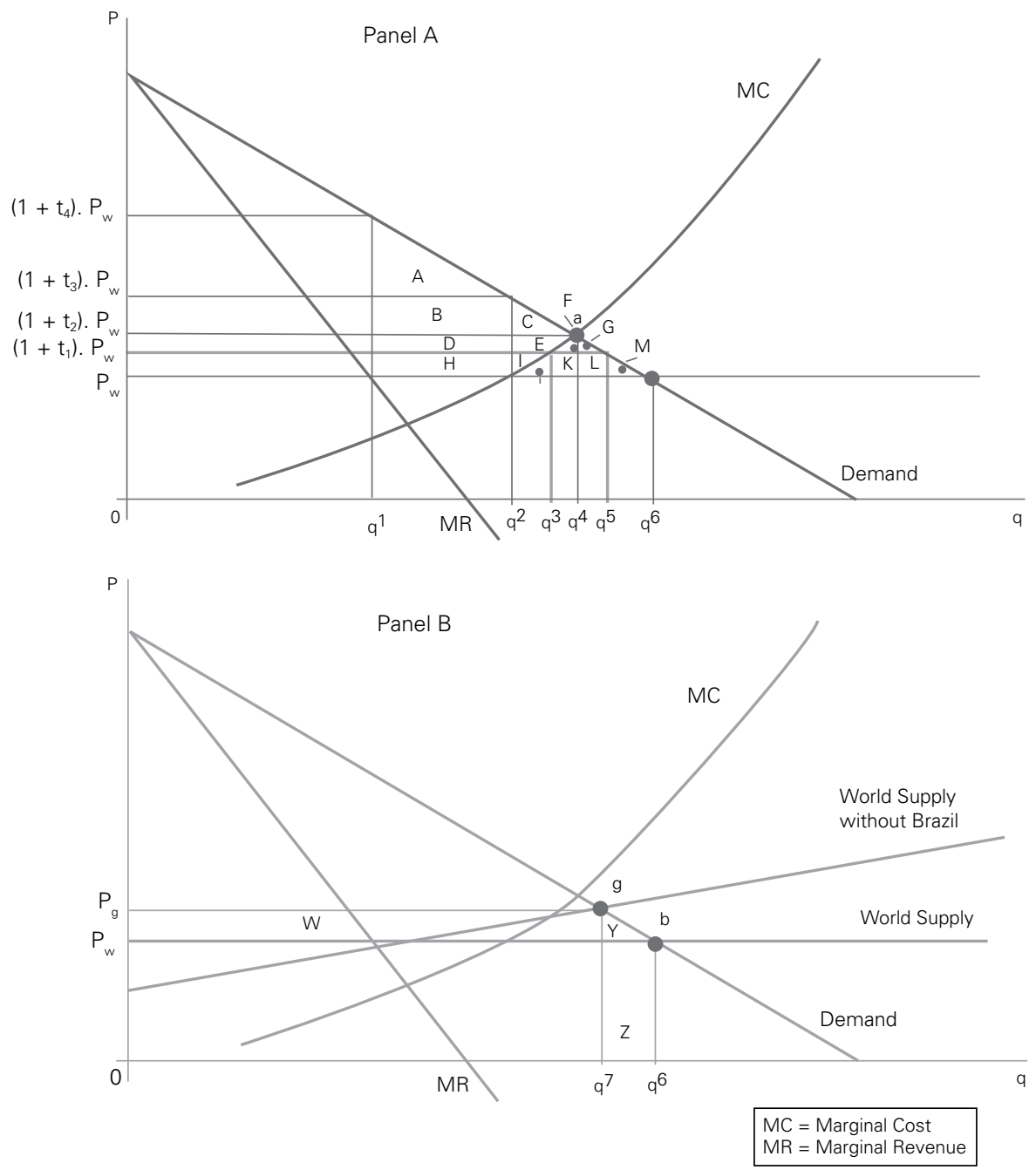

Panel $b$ shows the welfare effects of a discriminatory tariff imposed by a country that has a single producer, such as the case of UE tariffs on Brazilian soluble coffee imports. In such a case, a country sets a positive import tariff rate only on a specific producing country, so that it continues to engage in free trade with all remaining countries. Two possibilities exist here: if the world supply of soluble coffee continues to be infinitely elastic in the absence of the discriminated exporting country, there is no change in the welfare of the producing country that discriminates, so the equilibrium shall be $b$ point before and after the discriminatory tariff takes place. However, if the exclusion of the discriminated country's supply affects the world supply of the commodity, the curve will shift to a positive sloped world sup- 
ply, the new equilibrium will be attained at the $g$ point, and the discriminatory country will incur in a deadweight loss of the $\mathrm{Z}$ plus $\mathrm{Y}$ areas.

Although Brazil still remains with $15 \%$ of the soluble coffee world market, the country operates in a competitive way. Thus it is reasonable to believe that the elimination of its supply volume from the remaining global supply will significantly affect the latter. So, we supposed that discriminatory tariffs by UE countries on Brazilian soluble coffee cause inefficiencies in all of these countries, as depicted by panel $b$. Considering the deadweight loss $\mathrm{Z}$ and $\mathrm{Y}$, we conclude, after the discriminatory tariffs been applied, that the discriminating country will consume less and pay more for each unity of the commodity than if this discrimination was not done.

\section{THE ESTIMATION OF DEMAND FOR BRAZILIAN SOLUBLE COFFEE}

We used data from the following bodies: ABICS, Brazilian Central Bank, IFSIMF, Brazilian Foreign Trade Ministry and ICO. The panel data set includes all countries ${ }^{15}$ which-imported all types of Brazilian soluble coffee from 1995 until 2003. To get the estimates we used STATA software.

To verify whether discriminatory tariffs affect the demand for Brazilian soluble coffee, we estimated the foreign demand for Brazilian soluble coffee. We estimated linear fixed-effects models (FEM) in two stages using the generalized least square (GLS) estimator, along with dynamic models using the generalized method of moments (GMM) estimator proposed by Arellano and Bond (1991).

To evaluate the effects of customs tariffs on the Brazilian soluble coffee demand we utilized a variable which describes whether a buying country has or has not applied a tariff on the Brazilian good over time. We estimated two distinct specifications: one for tariffs evaluated by a dummy variable and the other for those evaluated by the percentage value of tariffs charged in each country. We supposed that the tariffs are exogenous and affect only the demand of soluble coffee.

\section{Fixed-Effects Model (FEM) estimates}

The use of the FEM allows the control of specific differences among countries in order to consistently estimate the parameters of concern (Islam, 1995). The estimated model is described in (1). $y$ is the vector of soluble coffee quantities imported by each country $i$ in each year $t ; \mathbf{x}$ is the matrix of the observable explanatory random variables, supposed to be linearly independent, which includes: the price in dollars of soluble coffee, $p_{i}$ each country's GDP per year as a proxy of aggregate income, $R_{i t}$; the percentage value of soluble coffee import tariffs in each

15 According to these data, 130 countries compose the sample. 
country in each period, $f_{i t}$ in one specification of the model and a dummy variable in other ( 1 for the existence of tariffs and 0 for their absence); each country's basic interest rate by year, $j_{i t}$; Singapore's and Malaysia's overall soluble coffee exports in each year - countries with the highest relative share of growth in the world market $^{16}, x m s_{t} . c$ is the matrix of the unobservable constant variable.

$$
E(y / \mathbf{x}, c)=\beta_{0}+\mathbf{x} \beta+c, y_{i t}=\mathbf{x}_{i t} \beta+c_{i}+u_{i t}
$$

One additional problem in estimating (1) lies in the identification of the model variables: the estimation of the demand function based on data from the market does not allow for a defined separation between demand and supply information. This causes endogeneity problems in the estimates of the demand model, thereby violating the basic hypothesis $\operatorname{Cov}\left(\mathbf{x}_{i}, u_{i}\right)=\mathbf{0}$, which ensures model efficiency in Ordinary Least Square (OLS) estimates. To identify the demand function we used the method of instrumental variables, even though we recognize that it is quite difficult to find an adequate instrument for the identification (Bond et al., 1995). Additionally, in order to avoid this problem, we estimated the dynamic models of demand proposed by Arellano and Bond (1991).

We used the price of the robusta green coffee paid to Brazilian producers ${ }^{17}, p i$, and the Brazilian real exchange rate in relation to the dollar, $t c_{t}$, as instruments for the soluble coffee price. The models estimates are shown in Table 5. The first two columns show the model with tariffs as percentages, and the two last ones show the model with dummy variables of tariffs. The $\mathrm{F}$ test ${ }^{18}$ rejects the null hypothesis for both models estimated, suggesting that there are specific relevant differences among the buyers of Brazilian soluble coffee.

Although Hausman's specification tests were favorable for the REM ${ }^{19}$, we chose the FEM because we considered that the income variable, introduced as a control in the model, is correlated with each country's specific characteristics. For instance, the habit and the taste of consuming coffee in its soluble form - an unobservable fixed effect in each country since soluble coffee is not an essential good must be related with the country's income (Baltagi, 2003; Wooldridge, 1997).

All variables in both models proved statistically significant at $1 \%$, except for the tariff dummy variable in the second model, which presented a $p$-value equal to 0.100 . This result suggests that the existence or non-existence of discriminatory tariffs does not affect the Brazilian soluble coffee demand; however, when the

\footnotetext{
${ }^{16}$ Note that although this variable varies just in $\mathrm{t}$, the matrix $\mathrm{x}$ applies this not only to case, but also when there are variables varying in $i$, but constant in $\mathrm{t}$.

17 Note that this variable only varies in $t$ because all countries $i$ that buy soluble coffee from Brazil in each time span have the same production cost for this good.

${ }^{18}$ It tests the whole significance of the fixed effect of the countries.

${ }^{19}$ Random Effect Model: the results of the tests presented $p$-values of 0.0751 and 0.3280 , respectively, for the Qui-square distribution.
} 
magnitude of the tariffs is considered, they proved to be significant to explain the quantity of soluble coffee demanded by the countries.

The coefficient associated with the exports from the Malaysia and Singapore variable, $x m s_{t}$, presented a negative sign, suggesting a substitution between the coffee sold by Brazil and that sold by other countries, which means that Brazil failed to export on account of competition. Those were the countries that most increased their participation in the soluble coffee world market over 1995-2003, as seen in Table 2, even though they do not produce green coffee.

The coefficient associated with the price variable presented a negative sign, as expected, for a demand function. Income, evaluated through each country's GDP, also presented an expected positive sign, showing that the higher the income, the higher the demand for soluble coffee. The interest rate variable and its lag presented, respectively, a negative and positive sign, showing that the higher the present interest rate, the smaller the demand, and that the higher the past interest rate, the higher is the demanded quantity. This result suggests that if the interest rate is high today, it is better to reduce consumption and that if it was high in the past, it is expected to drop in the present, thus increasing incentive for consumption.

\section{The Arellano-Bond Dynamic Panel Data Model}

The FEM estimates are is not efficient for the small period T, and for the models estimated in the last section it is possible to consider that the use of the lagged interest rate as an explicative variable may cause some endogeneity in the model. Thus, in order to improve our estimates we estimated dynamic models of demand proposed by Arellano and Bond (1991). Their idea of a dynamic panel data model consists in using lagged variables of both the explained and the explicative variables, in the more general case, as instruments. The estimated dynamic model consists of the first difference of equation (2), which removes $c_{i}$ and is based on the orthogonal conditions between the lagged values of $y_{i t}$ and $e_{i t}$.

$$
y_{i t}=\sum_{j=1}^{n} \alpha_{j} y_{i, t-j}+\mathbf{x}_{i t} \beta_{1}+\mathbf{w}_{i t} \beta_{2}+c_{i}+u_{i t}
$$

$\alpha_{j}, \beta_{1}$ and $\beta_{2}$ are vectors of parameters to be estimated; $\mathbf{x}_{i t}$ and $\mathbf{w}_{i t}$ are, respectively, the values of the exogenous variables and the predetermined variables; $c_{i}$ is the independent random effect, identically distributed (i.i.d.) in relation to the demanding countries and with a constant $\sigma_{c}^{2}$ variance. Finally, $u_{i t}$ is i.i.d. over the overall sample, which has a constant variance equal to $\sigma_{u}^{2}$.

Table 6 shows the Arellano-Bond dynamic model estimated by the GLS technique. Model (A) shows one-step estimates of the dynamic model for the panel of countries that bought Brazilian soluble coffee, under the hypothesis of homoskedasticity. Model (B) corresponds to model (A) corrected by heteroskedasticity of the residues. Model (C) is the Arellano-Bond's two-step estimate. All the models, estimated by the first difference, suggest that positive variations in the percentage values of discriminatory tariffs negatively affect the demanded quantity of Brazilian 
soluble coffee. Also, the variable that measures the first difference of Malaysia's and Singapore's exports has proven statistically significant with a negative sign in the three specifications, suggesting the substitution between the products exported by those countries and Brazil's. The signals of the estimates support the last section's results, though the values of the coefficients are not directly comparable because while the FEM is estimated by level, GLS models are estimated by differences.

Model (A) rejects the restrictions of Sargan's test of the over-identifying restrictions, but that may have occurred due to problems of heteroskedasticity. In $(\mathrm{C})$, however, neither the null hypotheses of constraints are valid, nor the hypotheses of first and second order correlation are rejected, suggesting an improvement in the efficiency of the estimated model. Arellano and Bond (1991) recommend the use of one-step estimates for the inference because two-step estimates of the standard errors tend to be biased down in small samples, which makes coefficients more significant, as can be verified in (C). Nevertheless, as the results of the model are quite similar and the inference that interests us is the same based on any model, this issue becomes irrelevant to our results.

Besides the models discussed in this article, which do not discriminate among the different types of soluble coffee, we sought ${ }^{20}$ to estimate models of demand for Brazilian soluble coffee considering the different types of soluble coffee ${ }^{21}$. The FEMs calculated have not generated adequate estimates because we used the same instruments for the different types of soluble coffee. Preliminary estimates of dynamic demands by GLS for each type of soluble coffee, an exercise that still requires a search for better specifications and that is not the object of this article, suggest a few interesting preliminary results, among which is that the demand for soluble coffee in bulk seems not to be affected by discriminatory tariffs ${ }^{22}$.

\section{CONCLUSIONS}

The results of the estimated models suggest that discriminatory and non-discriminatory tariffs had a negative impact on the world demand for Brazilian soluble coffee during the period examined. This may imply that Brazil's relative loss of market is partly associated with the imposition of discriminatory tariffs by the EU and by import substitution tariffs adopted by some Eastern European countries.

\footnotetext{
${ }^{20}$ We have additionally estimated the dynamic models (A), (B) and (C) with the tariffs dummies. These have shown the same pattern of result as the FEM: not statistically significant, but near the acceptance limit of the null hypothesis. Also, we have estimated versions of the dynamic models of demand considering some variables to be predetermined, but the statistical results did not differ from those obtained in Table 5 .

${ }^{21}$ Data for exports of soluble coffee obtained allow discrimination among buyers of each type of soluble coffee.

22 This may obviously be a problem generated by a bad specification of the model, but the results find support in the market analysis.
} 
Additionally, results suggest that Malaysia and Singapore - the two countries that most increased their relative share in the world market in the last years - significantly affected the demand for Brazilian soluble coffee. This fact configures those countries as substitute suppliers of the Brazilian good, even though neither of them produces green coffee, the main input of soluble coffee.

Considering the size of the Brazilian soluble coffee production capacity, the imposition of discriminatory and non-discriminatory tariffs apparently opened profitable possibilities for new entrants, including countries that are not traditional producers of coffee grain input, in particular some Asian and European countries. Thus, the imposition of tariffs on the largest exporter of soluble coffee, added to the growth of the world soluble coffee market, resulted in new producers and exporters in the market, even though they are not efficient and do not have comparative advantage.

Although Brazil is the biggest producer in the world, it does not exercise market power in the soluble coffee trade. Nevertheless, the imposition of tariffs by countries without comparative advantage results in economic inefficiencies. In terms of strategy, some possibilities exist for Brazil to address the problem of loss of welfare: a) to toughen its position at the WTO demanding the fall of discriminatory pricing restrictions and of tariff barriers in general; b)to demand or to make an impact evaluation of the anti-drug policy (the Drug Regime), in which case the strategy would be collective and involve national governments; c) the opening of firms abroad, in Europe and Asia, seeking to take advantage of special fares and lower costs of workforce, respectively. Whereas this last strategy is mainly private - within the firms -, the former ones involve both government and society.

\section{REFERENCES}

ABIC (2005). Brazilian soluble industry association. statistics. Available at http://www.abic.com.br/ estatisticas.html. Accessed in June.

ABICS (2005). Brazilian soluble industry association. São Paulo, Statistical data from the Association. ARELLANO, M., and BOND, S. (1991). "Some tests of specification for panel data: Monte Carlo evidence and application to employment equations". Review of Economic Studies, 58, p. 277 297.

BALTAGI, B. H (2003), Econometric Analysis of Panel Data, Chichester: John Wiley \& Sons, Ltd, second edition.

BOND, J., D. A. JAEGER, and BAKER, R. M. (1995). "Problems with instrumental variables estimation when the correlation between the instruments and the endogenous explanatory variables is weak". Journal of the American Statistical Association, vol. 90, $\mathrm{n}^{\circ} 430$.

CECAFÉ (2005). Council of Brazilian green coffee exporters. Statistical data from http://www.cecafe. com.br/ June.

ICO (2005). International coffee organization statistics from http://www.ico.org.

ISLAN, N. (1995). "Growth empirics: a panel data approach". The Quarterly Journal of Economics, vol. $11, \mathrm{n}^{\circ}$ 4, p. 1127-70.

MALTA, Mauro. Interviewed in August 2004.

OFFICIAL JOURNAL OF THE EUROPEAN COMMUNITIES (OJEC) (2001). Council regulation (EC) No 2165. L 292, p. 1-2. 
PONTE, S. (2002). "The late revolution? Regulation, markets and consumption in the global coffee chain”. World Development, vol. 30, n.7, p. 1099-1122.

RIEBER, W. J. (1981). "Tariffs as means of altering trade patterns”. American Economic Review, vol. 71, n.5, p. 1098-1099.

SAES, M. S. M and NAKAZONE, D. (2003). "El estudio de competitividad de cadenas integradas en el Brasil”, In Ensayos sobre Economia Cafetera. Bogotá, no. 19, p. 11-68.

SAES, M. S. M. (1997). A Racionalidade Econômica da Regulamentação do Mercado de Café. São Paulo: Annablume / Fapesp.

TALBOT, J. M. (1997). "The struggle for control of a commodity chain: instant coffee from Latin American." Latin American Research Review, vol. 32, n.2, p. 117-135.

WOOLDRIDGE, J. M. (1997) Econometric Analysis of Cross Section and Panel Data, London: MIT Press.

ZYLBERSTAJN, D. et al. (1993). O Sistema Agroindustrial do Café: um estudo da organização do agribusiness do café visto com a chave da competitividade. Porto Alegre: Editora Ortiz.

Table 1: World soluble coffee exports (thousand bags) - percentage per exporting countryw

\begin{tabular}{|c|c|c|c|c|c|c|c|c|c|}
\hline Period & 1995 & 1996 & 1997 & 1998 & 1999 & 2000 & 2001 & 2002 & Change \\
\hline $\begin{array}{l}\text { Total PERCENTAGE } \\
\text { Exported by country } \\
\text { (thousand bags ) }\end{array}$ & 8744 & 9783 & 11023 & 10891 & 11424 & 13635 & 15842 & 16935 & $94 \%$ \\
\hline Total Exported & $100 \%$ & $100 \%$ & $100 \%$ & $100 \%$ & $100 \%$ & $100 \%$ & $100 \%$ & $100 \%$ & \\
\hline Producing countries & $52 \%$ & $46 \%$ & $43 \%$ & $39 \%$ & $37 \%$ & $34 \%$ & $34 \%$ & $32 \%$ & $-20 \%$ \\
\hline Brazil & $29 \%$ & $26 \%$ & $22 \%$ & $15 \%$ & $17 \%$ & $15 \%$ & $16 \%$ & $15 \%$ & $-14 \%$ \\
\hline Colômbia & $6 \%$ & $6 \%$ & $6 \%$ & $6 \%$ & $5 \%$ & $4 \%$ & $4 \%$ & $4 \%$ & $-2 \%$ \\
\hline Ecuador & $5 \%$ & $3 \%$ & $3 \%$ & $4 \%$ & $3 \%$ & $2 \%$ & $2 \%$ & $2 \%$ & $-3 \%$ \\
\hline México & $3 \%$ & $2 \%$ & $2 \%$ & $2 \%$ & $2 \%$ & $2 \%$ & $3 \%$ & $2 \%$ & $-1 \%$ \\
\hline Índia & $5 \%$ & $4 \%$ & $5 \%$ & $5 \%$ & $4 \%$ & $5 \%$ & $5 \%$ & $4 \%$ & $0 \%$ \\
\hline Indonésia & $0 \%$ & $1 \%$ & $1 \%$ & $2 \%$ & $2 \%$ & $2 \%$ & $1 \%$ & $1 \%$ & $1 \%$ \\
\hline Ivory Coast & $2 \%$ & $3 \%$ & $3 \%$ & $4 \%$ & $4 \%$ & $3 \%$ & $3 \%$ & $3 \%$ & $0 \%$ \\
\hline Consuming countries & $48 \%$ & $54 \%$ & $57 \%$ & $61 \%$ & $63 \%$ & $66 \%$ & $66 \%$ & $68 \%$ & $20 \%$ \\
\hline US & $3 \%$ & $6 \%$ & $7 \%$ & $5 \%$ & $6 \%$ & $6 \%$ & $5 \%$ & $5 \%$ & $2 \%$ \\
\hline Canadá & $3 \%$ & $3 \%$ & $3 \%$ & $6 \%$ & $4 \%$ & $3 \%$ & $2 \%$ & $2 \%$ & $-1 \%$ \\
\hline France & $5 \%$ & $5 \%$ & $5 \%$ & $5 \%$ & $4 \%$ & $4 \%$ & $4 \%$ & $4 \%$ & $0 \%$ \\
\hline Germany & $9 \%$ & $10 \%$ & $9 \%$ & $10 \%$ & $10 \%$ & $11 \%$ & $10 \%$ & $11 \%$ & $2 \%$ \\
\hline Holland & $3 \%$ & $3 \%$ & $2 \%$ & $6 \%$ & $7 \%$ & $6 \%$ & $6 \%$ & $6 \%$ & $3 \%$ \\
\hline Spain & $2 \%$ & $3 \%$ & $3 \%$ & $3 \%$ & $2 \%$ & $3 \%$ & $5 \%$ & $5 \%$ & $3 \%$ \\
\hline UK & $6 \%$ & $5 \%$ & $4 \%$ & $5 \%$ & $5 \%$ & $4 \%$ & $4 \%$ & $4 \%$ & $-2 \%$ \\
\hline Switzerland & $2 \%$ & $2 \%$ & $2 \%$ & $2 \%$ & $2 \%$ & $2 \%$ & $2 \%$ & $2 \%$ & $0 \%$ \\
\hline Singapore & $5 \%$ & $6 \%$ & $7 \%$ & $7 \%$ & $7 \%$ & $0 \%$ & $9 \%$ & $10 \%$ & $5 \%$ \\
\hline Malaysia & $1 \%$ & $1 \%$ & $1 \%$ & $2 \%$ & $3 \%$ & $5 \%$ & $7 \%$ & $7 \%$ & $6 \%$ \\
\hline China (and Hong Kong) & $0 \%$ & $0 \%$ & $0 \%$ & $1 \%$ & $1 \%$ & $1 \%$ & $1 \%$ & $1 \%$ & $0 \%$ \\
\hline
\end{tabular}

Source: International Coffee Organization (2005). 
Table 2: Tariffs applicable to Brazilian soluble coffee in the EU

\begin{tabular}{lc}
\hline YEAR & Tariff \\
\hline 1991 to 31.12 .96 & $9,0 \%$ \\
01.0197 to 30.06 .97 & $10,1 \%$ \\
01.07 .97 to 31.12 .97 & $9,1 \%$ \\
01.01 .98 to 30.06 .98 & $9,1 \%$ \\
01.07 .98 to 31.12.98 & $8,0 \%$ \\
01.01 .99 to 31.12.99 & $10,5 \%$ \\
01.01 .2000 onwards & $9,0 \%$ \\
\hline
\end{tabular}

Source: MALTA (2004).

Table 3: EU: soluble coffee imports per origin (equivalent to a thousand $60 \mathrm{~kg}$ bags)

\begin{tabular}{|c|c|c|c|c|c|c|c|c|c|c|}
\hline & 1970 & 1980 & 1990 & 1993 & 1995 & 1998 & 1999 & 2000 & 2002 & 2003 \\
\hline TOTAL & 1206,1 & 2135,1 & 2329,9 & 2281,5 & 2563,5 & 3626,5 & 3483,4 & 3878,6 & 4405,0 & 4610,6 \\
\hline Brazil & 377,3 & 869,0 & 359,1 & 468,1 & 270,4 & 262,1 & 215,1 & 261,6 & 355,1 & 401,3 \\
\hline Colombia & 0,6 & 18,7 & 179,3 & 140,9 & 190,5 & 238,6 & 204,6 & 243,1 & 167,8 & 154,8 \\
\hline Costa Rica & - & - & - & & - & 6,1 & 1,1 & 0,6 & 1,7 & 1,5 \\
\hline Ecuador & 0,0 & 49,1 & 86,7 & 99,7 & 119,9 & 219,4 & 173,8 & 159,0 & 193,3 & 195,3 \\
\hline Índia & 0,0 & 0,0 & 3,5 & 23,9 & 4,7 & 12,2 & 6,6 & 15,0 & 14,6 & 14,3 \\
\hline Indonesia & - & - & - & - & - & 10,2 & 6,6 & 22,4 & 12,3 & 6,0 \\
\hline México & 0,0 & 11,5 & 0,0 & 9,4 & 46,6 & 4,0 & 4,4 & 1,8 & 1,6 & 1,4 \\
\hline Nicaragua & - & - & - & & - & 9,6 & 13,3 & 12,4 & 17,9 & 5,6 \\
\hline Ivory Coast & 19,2 & 71,5 & 195,2 & - & - & 292,2 & 295,1 & 267,2 & 291,8 & 196,2 \\
\hline Tanzânia & - & - & - & - & - & 5,5 & 4,1 & 5,4 & 2,9 & 4,1 \\
\hline Thailand & - & - & - & - & - & 4,6 & 4,3 & 2,1 & 0,5 & 0,4 \\
\hline Venezuela & - & - & - & - & - & 5,4 & 14,8 & 21,7 & 26,1 & 22,8 \\
\hline E.U. & 604,9 & 959,4 & 1389,9 & 1692,3 & 2167,8 & 2337,3 & 2338,9 & 2648,9 & 3017,8 & 3324,8 \\
\hline Brazil/EU & $31,3 \%$ & $40,7 \%$ & $15,4 \%$ & $20,5 \%$ & $10,5 \%$ & $7,2 \%$ & $6,2 \%$ & $6,7 \%$ & $8,1 \%$ & $8,7 \%$ \\
\hline EU/ & $50,2 \%$ & $44,9 \%$ & $59,7 \%$ & $74,2 \%$ & $84,6 \%$ & $64,5 \%$ & $67,1 \%$ & $68,3 \%$ & $68,5 \%$ & $72,1 \%$ \\
\hline
\end{tabular}

Source: International Coffee Organization (2005). 
Table 4: Major Brazilian soluble coffee markets (equivalent to thousand $60 \mathrm{~kg}$ bags)

\begin{tabular}{|c|c|c|c|c|c|c|c|c|c|}
\hline Country/Year & 1995 & 1997 & 1998 & 2000 & 2003 & $\begin{array}{c}\text { var. } \\
\text { 1997/ } 1995\end{array}$ & $\begin{array}{c}\text { Var. } \\
\text { 1998/ } 1995\end{array}$ & $\begin{array}{c}\text { var. } \\
\text { 2000/ } 1995\end{array}$ & $\begin{array}{c}\text { var. } \\
2003 / 1995\end{array}$ \\
\hline Rússia & 1102,7 & 737,9 & 393,2 & 315,0 & 359,0 & $-33 \%$ & $-64 \%$ & $-71 \%$ & $-67 \%$ \\
\hline US & 425,4 & 299,8 & 307,7 & 480,2 & 546,2 & $-30 \%$ & $-28 \%$ & $13 \%$ & $28 \%$ \\
\hline Japan & 207,5 & 246,4 & 214,2 & 260,8 & 301,9 & $19 \%$ & $3 \%$ & $26 \%$ & $45 \%$ \\
\hline Germany & 157,1 & 129,0 & 188,2 & 226,7 & 286,0 & $-18 \%$ & $20 \%$ & $44 \%$ & $82 \%$ \\
\hline România & 155,6 & 77,9 & 55,7 & 25,5 & 24,2 & $-50 \%$ & $-64 \%$ & $-84 \%$ & $-84 \%$ \\
\hline UK & 122,4 & 71,5 & 23,9 & 6,6 & 109,8 & $-42 \%$ & $-80 \%$ & $-95 \%$ & $-10 \%$ \\
\hline Canadá & 58,0 & 38,1 & 37,6 & 26,1 & 22,4 & $-34 \%$ & $-35 \%$ & $-55 \%$ & $-61 \%$ \\
\hline Finland & 42,7 & 1,7 & 4,5 & 34,7 & 31,5 & $-96 \%$ & $-89 \%$ & $-19 \%$ & $-26 \%$ \\
\hline Austrália & 38,1 & 50,9 & 55,8 & 34,4 & 21,2 & $34 \%$ & $46 \%$ & $-10 \%$ & $-44 \%$ \\
\hline Poland & 36,8 & 57,7 & 26,5 & 6,8 & 20,2 & $57 \%$ & $-28 \%$ & $-82 \%$ & $-45 \%$ \\
\hline México & 34,8 & 40,9 & 21,2 & 14,8 & 21,1 & $18 \%$ & $-39 \%$ & $-57 \%$ & $-39 \%$ \\
\hline Singapore & 32,1 & 50,7 & 35,4 & 62,7 & 99,1 & $58 \%$ & $10 \%$ & $95 \%$ & $209 \%$ \\
\hline Argentina & 25,5 & 33,9 & 31,9 & 45,9 & 112,1 & $33 \%$ & $25 \%$ & $80 \%$ & $340 \%$ \\
\hline Ukraine & 13,0 & 330,2 & 74,9 & 307,6 & 317,0 & $2440 \%$ & $476 \%$ & $2266 \%$ & $2338 \%$ \\
\hline Spain & 5,6 & 1,2 & 1,2 & 1,3 & 31,1 & $-79 \%$ & $-79 \%$ & $-77 \%$ & $455 \%$ \\
\hline Uruguay & 3,7 & 6,6 & 8,0 & 8,2 & 26,9 & $78 \%$ & $116 \%$ & $122 \%$ & $627 \%$ \\
\hline Czech Rep. & 1,9 & 2,0 & 28,0 & 73,6 & 77,8 & $5 \%$ & $1374 \%$ & $3774 \%$ & $3995 \%$ \\
\hline Malaysia & 1,2 & 2,3 & 0,6 & 18,3 & 70,0 & $92 \%$ & $-50 \%$ & $1425 \%$ & $5733 \%$ \\
\hline Lithuania & 1,1 & 7,4 & 6,0 & 1,1 & 57,4 & $573 \%$ & $445 \%$ & $0 \%$ & $5118 \%$ \\
\hline China & 0,8 & 0,6 & 1,3 & 2,6 & 6,6 & $-25 \%$ & $63 \%$ & $225 \%$ & $725 \%$ \\
\hline El Salvador & - & - & - & - & 34,7 & & & & - \\
\hline Korea DPR & - & 2,9 & 1,6 & 2,7 & 19,6 & & & & - \\
\hline Others & 148,7 & 144,7 & 144,6 & 110,6 & 252,1 & $-3 \%$ & $-3 \%$ & $-26 \%$ & $70 \%$ \\
\hline TOTAL & 2615 & 2334 & 1662 & 2066 & 2848 & $-11 \%$ & $-36 \%$ & $-21 \%$ & $9 \%$ \\
\hline
\end{tabular}

Source: CECAFÉ (2005).

Table 5: FEM-IV estimates of the Brazilian soluble coffee demand

\begin{tabular}{|c|c|c|c|c|}
\hline \multirow{2}{*}{$\begin{array}{l}\text { Explained variable } \\
\mathrm{q}_{\mathrm{it}}\end{array}$} & \multicolumn{2}{|c|}{ Model with percentage tariff } & \multicolumn{2}{|c|}{ Model with tariff in binary form } \\
\hline & Coefficient & Standard error & Coefficient & Standard error \\
\hline pit & $-35.39995^{* * *}$ & 8.424229 & $-35.77469 * * *$ & 8.511825 \\
\hline fit & $-3.725526 * * *$ & 1.535462 & $-40.99827^{*}$ & 25.42196 \\
\hline Rit & $0.0000702 * *$ & 0.0000309 & $0.0000719^{* *}$ & 0.0000311 \\
\hline xmst & $-0.0267248 * * *$ & 0.0098739 & $-0.0263614 * * *$ & 0.010044 \\
\hline$j_{\text {it }}$ & $-1.751061^{* * *}$ & 0.6478176 & $-1.818003^{* * *}$ & 0.6528098 \\
\hline $\mathrm{j}_{\mathrm{i}(\mathrm{t}-1)}$ & $4.579189 * * *$ & 0.0098739 & $4.580427^{* * *}$ & 0.5046107 \\
\hline
\end{tabular}




\begin{tabular}{|c|c|c|c|c|}
\hline Constant & $299.4314 * * *$ & 61.70793 & $287.9982 * * *$ & 62.88322 \\
\hline $\begin{array}{l}F \text { test that all } \\
u_{-} i=0,(\text { Prob }>F)\end{array}$ & $19.18(0.0000) * * *$ & & $18.08(0.0000)$ & \\
\hline Wald chi2(6) & $636.20 * * *$ & & $620.89 * * *$ & \\
\hline Number of obs. & 351 & & 351 & \\
\hline Instrument & $\mathrm{p}_{\text {it }} \mathrm{e} \mathrm{tc}_{\mathrm{t}}$ & & $\mathrm{p}_{\text {it }}$ e tc & \\
\hline
\end{tabular}

*** Significant at $1 \% ;{ }^{*}$ significant at $5 \%$; ${ }^{*}$ significant at $10 \%$

Table 6: GMM estimates of the world demand for Brazilian soluble coffee

\begin{tabular}{|c|c|c|c|}
\hline \multicolumn{4}{|c|}{ Equations for world demand for Brazilian soluble coffee } \\
\hline \multicolumn{4}{|c|}{ GLS (All variables are first differenced) } \\
\hline $\begin{array}{l}\text { dep. var. } \\
\text { qit }\end{array}$ & (A) One Step & (B) One-Step Robust & (C) Two Step \\
\hline qi(t-1) & $0.1705(0.0610)^{* * *}$ & $0.1705(0.0263)^{* * *}$ & $0.1705(0.0020)^{* * *}$ \\
\hline qi(t-2) & $0.1513(0.0458)^{* * *}$ & $0.1513(0.0687)^{* *}$ & $0.1503(0.00168)^{* * *}$ \\
\hline pit & $-6.9780(3.9958)^{*}$ & $-6.9780(3.2496)^{* *}$ & $-6.629508(0.2745)^{* * *}$ \\
\hline pi(t-1) & $1.9161(4.1644)$ & $1.9162(2.5819)$ & $2.2146(0.6217)^{* * *}$ \\
\hline fit & $-3.1718(1.5645)^{* *}$ & $-3.1718(1.2900)^{* * *}$ & $-3.1535(0.1190)^{* * *}$ \\
\hline fi(t-1) & $0.7782(1.8474)$ & $0.7782(1.7416)$ & $0.7906(0.0364)^{* * *}$ \\
\hline Rit & $0.00015(0.000054)^{* * *}$ & $0.00015(0.000073)^{* * *}$ & $0.00015(6.53 \mathrm{e}-06)^{* * *}$ \\
\hline $\operatorname{Ri}(t-1)$ & $0.000016(5.4 e-5)$ & $0.000016(0.000063)^{*}$ & $0.000018(3.79 \mathrm{e}-06)^{* * *}$ \\
\hline xmst & $-0.013445(0.0067)^{* *}$ & $-0.01345(0.0146)$ & $-0.0133(0.00048)^{* * *}$ \\
\hline$x m s(t-1)$ & $0.00858(0.0226)$ & $0.00858(0.03533)$ & $0.0098(0.0016)^{* * *}$ \\
\hline jit & $-2.8260(0.6562)^{* * *}$ & $-2.8260(1.6277)^{*}$ & $-2.8051(0.04868)^{* * *}$ \\
\hline jil(t-1) & $2.5881(0.6546)^{* * *}$ & $2.5881(1.4448)^{*}$ & $2.5994(0.04363)^{* * *}$ \\
\hline Constant & 8.4719 (8.5702) & 8.4719 (10.9508) & $7.9566(1.4414)^{* * *}$ \\
\hline Number of obs & 216 & 216 & 216 \\
\hline Sargan test & $\begin{array}{l}\operatorname{chi} 2(33)=202.12 \\
\text { Prob }>\text { chi } 2=0.0000\end{array}$ & - & $\begin{array}{l}\operatorname{chi} 2(33)=35.00 \\
\text { Prob }>\text { chi2 }=0.3732\end{array}$ \\
\hline Wald test & 154.01 & 1201.54 & $2.85 e+07$ \\
\hline $\begin{array}{l}\text { A_B test } \\
\text { autocovariance } \\
\text { order } 1\end{array}$ & $\begin{array}{l}z=-4.33 \\
\operatorname{Pr}>z=0.0000\end{array}$ & $\begin{array}{l}z=-1.48 \\
\operatorname{Pr}>z=0.1376\end{array}$ & $\begin{array}{l}z=-1.28 \\
\operatorname{Pr}>z=0.2016\end{array}$ \\
\hline $\begin{array}{l}\text { A_B test } \\
\text { autocovariance } \\
\text { order } 2\end{array}$ & $\begin{array}{l}z=0.48 \\
\operatorname{Pr}>z=0.6294\end{array}$ & $\begin{array}{l}z=0.37 \\
\operatorname{Pr}>z=0.7099\end{array}$ & $\begin{array}{l}z=0.25 \\
\operatorname{Pr}>z=0.7989\end{array}$ \\
\hline
\end{tabular}

*** Significant at 1\%; * significant at $5 \%$; ${ }^{*}$ significant at $10 \%$ 